Artigo Técnico

\title{
O futuro do mercado de plantas
}

\author{
AUGUSTO AKI (1)
}

O segmento de paisagismo sempre foi o menos organizado da cadeia de flores. Ainda que no Veiling existam produtos desse grupo, a comercialização de Holambra está mais focada em flores de corte e flores em vaso. Acontece que a explosão imobiliária que presenciamos nos últimos anos cria mercado e demanda para as plantas e essa demanda não era melhor aproveitada até agora devido às deficiências de organização dessa cadeia produtiva.

A produção pode ser feita em todos os rincões do País, o que torna o segmento uma excelente opção para o produtor regional. A padronização dos produtos, o controle de qualidade, a apresentação e os canais de venda, contudo, sempre foram ineficientes. O modelo hoje é composto de viveiros e Ceasas regionais e linheiros de Dona Eusébia.

Os estados de $\mathrm{SC}, \mathrm{GO}, \mathrm{RS}$ e $\mathrm{SP}$ são os principais produtores. Existem, contudo bolsões de produtividade, ligados às condições climáticas, como o caso da ixora em Mato Grosso.

Fazendo uma analogia com a cadeia de flores em vaso, podemos perceber que a cadeia de plantas começa agora a configurar-se por "níveis" a partir do estágio de comercialização e essa estratificação está construindo o novo modelo logístico para a cadeia.

Olhemos em primeiro lugar os níveis de comercialização:

- Nível I - Veiling, SP Flores, SC e RS - o produto é vendido diretamente pelo produtor a preços do produtor. Tem alcance nacional. A venda mais forte acontece duas vezes por semana. Alto nível de organização administrativa e controles financeiros. Boa padronização de produtos. O custo de comercialização é baixo. A adesão e fidelidade dos produtores é fator estratégico.

- Nível II - Ceasa Campinas, Holambelo e Fast Flores. Nesse nível a comercialização é feita tanto pelo produtor como por atacadistas. O nível de preços é mais elevado, pois esses agentes consolidam o "mix" revendendo produtos das regiões do nível I. Tem alcance regional. A venda mais forte ainda acontece duas vezes por semana. Bom nível de organização administrativa e controles financeiros. $\mathrm{O}$ custo de comercialização é uma preocupação. A malha de compras é fator estratégico.
- Nível III - Ceagesp SP, Garden Uemura/SP, Tatuapé Garden/SP, Garden Morumbi, COBASI/SP e ABC Garden/SP. Neste nível acontece tanto a venda ao consumidor quanto a revenda no atacado. Movimentam grandes volumes, o nível de preços é maior e organizam suas compras nos pólos do Nível I e II (e também de produtores locais). Tem alcance microrregional. A venda se distribui durante toda a semana (isso também acontece em todos os níveis posteriores). Organização administrativa razoável. Apresentam produtos com problemas de padronização (devido à base de compra mais pulverizada). O custo de comercialização é desconhecido. A gestão de estoques é fator estratégico.

- Nível IV - Rede Ponto Flores em SP, depósitos regionais de atacadistas e grandes viveiros do Centro-Oeste - venda direta ao consumidor final. Mesclam a venda de plantas com venda de outros produtos de decoração. Compram no nível III e de atacado que passam a sua porta. Têm preço maior que os canais anteriores e procuram agregar serviços ao consumidor final. Têm alcance local. Boa força em promoção de produtos (que é seu fator estratégico).

- Nível V - viveiros, hortos e floriculturas - atendem ao microlocal, com pequenos estoques. A estratégia pode ser de preço ou de valor agregado. Em geral compram no atacado que faz linha até suas lojas. Organização administrativa sofrível e controles financeiros ruins. O faturamento por $\mathrm{m}^{2}$ é o fator estratégico.

- Nível VI - Quiosques e feirantes - semelhante ao nível $\mathrm{V}$, movimentando, contudo menos volume, menor "mix" e com mobilidade. O volume de faturamento semanal é o fator estratégico.

\section{Destaques:}

- Para os mercados regionais, o modelo mais indicado é o Nível III. Nele podemos conciliar a logística de compra com o Nível II, completando o "mix" de produtos local, atender tanto ao atacado quanto ao varejo local e ainda ter uma saída para outros estados. A Holambelo tem se mostrado um importante agente integrados dessa cadeia, interligando produtos entre as

${ }^{(1)}$ Consultor. e-mail: augustoaki@dglnet.com.br.www.negocioscomflores.com.br 
regiões em que atua. É necessário, contudo, que o ponto de venda seja constituído de forma organizada pelos produtores locais.

- Com a inauguração do novo Veiling (e as novas taxas), assim como com o crescimento do varejo no Ceasa Campinas, devemos ter uma valorização do Nível II que passará a concentrar as cargas do mercado de atacado.

A demanda de plantas nos mercados locais cria muitas oportunidades. A Copa do Mundo cria outro grupo ainda maior, para todo o setor. Conciliar a produção de paisagismo com tropicais, ou folhagens ou ainda flores de corte nos núcleos de produção regional é uma forma legal de fortalecer o fluxo de caixa do produtor. Para isso, no entanto, precisamos entender a melhor combinação para a comercialização no local. Muitos núcleos de produção tentam ser Nível I e com isso perdem força. O Nível II é desejado como objetivo, mas não como início. Viabilizar um local que seja ao menos Nível III é a grande sacada para o início de uma boa escalada. 